Brit. F. industr. Med., 1967, 24, 1

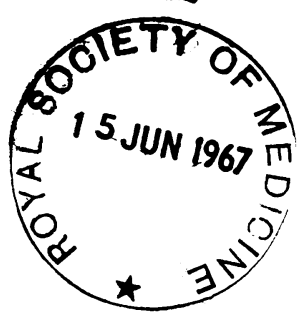

\title{
Chronic Bronchitis in Miners and Non-miners : An Epidemiological Survey of a Community in the Gold-mining Area in the Transvaal ${ }^{1}$
}

\author{
G. K. SLUIS-CREMER, L. G. WALTERS, and H. S. SICHEL \\ From the Miners' Medical Bureau, the Pneumoconiosis Research Unit and the \\ Operational Research Bureau, fohannesburg
}

An epidemiological survey to determine the prevalence of chronic bronchitis in a mixed mining and non-mining population of Carletonville on the Witwatersrand is described. Eight hundred and twentyseven men over the age of 35 years were investigated.

Chronic bronchitis is shown to be significantly more common in miners than in non-miners for every age and smoking category with the exception of the non-smoker. In the non-smoker no significant difference exists in the prevalence of chronic bronchitis between the mining and non-mining groups.

Smoking habits were found to have overwhelming effects on the prevalence of chronic bronchitis in both groups.

It is suggested that a synergistic interplay of smoking and general underground aerial pollution (rather than dust inhalation alone) is responsible for the excess prevalence of chronic bronchitis in the miner who smokes.

Extensive research has taken place in the last Io years on many aspects of chronic bronchitisclinical, pathological, physiological, and epidemiological. One facet of the latter that has been treated with sustained interest is the relative prevalence of the condition in various occupations and especially the dust-exposed occupations.

Of these, coal-mining has been most intensively studied. A higher prevalence of symptoms of chronic bronchitis in coal-miners has been reported by many workers in recent years from Britain, America, Germany, and elsewhere (Higgins and Cochrane, I96I ; Higgins, Cochrane, Gilson, and Wood, 1959; Böhme and Lent, I95I; Pemberton, 1956; Carpenter, Cochrane, Gilson, and Higgins, 1956; Higgins, Oldham, Cochrane, and Gilson, 1956; Hyatt, Kistin, and Mahan, 1964; Vyskočil, 1964).

Whether or not the prevalence of symptoms, or their intensity, increases with increasing length of dust exposure or increasing length of underground work remains a controversial matter. Higgins and Cochrane (196I) could not show such a relationship

${ }^{1}$ This study was carried out under the auspices of the Pneumoconiosis Research Unit of the South African Council for Scientific and Industrial Research.

Received for publication April 29, 1966. whereas Hyatt et al. (1964) and Worth, Ibel, Durben, and Gasthaus (1958) claim that there is a correlation. In any case, there is no good evidence that the respiratory symptoms in coal-miners are in fact due to the inhalation of dust.

It appeared important to determine whether there is also an increased prevalence in workers in the South African gold-mines. These workers are exposed to quantitatively low dust exposures with high free silica content $(50 \%$ to $70 \%$ ) in contrast to the high dust levels with low silica content in coal-mines.

Previous studies in South Africa have suggested that, in gold-miners suffering from dyspnoea but without evidence of silicosis, there is no significant relationship between the grade of dyspnoea and dust exposure but dyspnoea was correlated with evidence of airway obstruction and with hyperventilation on effort. Dyspnoeic men had a high incidence of cough, sputum, and rhonchi, suggesting that bronchitis was the likely cause (Zwi, I960).

No studies comparing the prevalence of chronic bronchitis in miners and ex-miners and non-miners from a geographically defined population have as yet been carried out on South African gold-miners. Indeed, no such comparative studies between miners and non-miners on any variety of random samples have been carried out.

A study by Zwi and Becklake (1958) showed no difference in the incidence of chronic bronchitis 
between a random sample of gold-miners and an age-matched group of volunteer railway workers.

A study of this kind, it was considered, would also provide an opportunity to compare the prevalence of chronic bronchitis on the high veld of South Africa with that obtained in other countries. For this reason, in addition to its intrinsic merits, the long questionnaire (I96I) approved by the British Medical Research Council's Committee on the Aetiology of Chronic Bronchitis, which has been used in several international comparative studies, was adopted for this survey.

\section{Methods}

The Community It was necessary that the geographically defined community which it was desired to investigate should have the following characteristics:-

I. It should contain sufficient numbers of miners and non-miners (the term 'miners' includes exminers) to give adequate samples in the age groups of interest, i.e., men over 35 years.

2. The population should be relatively stable and be as homogeneous as possible in socio-economic status.

3. There should be a minimum of general air pollution.

The town of Carletonville, about 40 miles from Johannesburg, appeared to fulfil these demands. The town is at an altitude of approximately $5,000 \mathrm{ft}$. $(\mathrm{I}, 524 \mathrm{~m}$.). The municipal area is 94 square miles $\left(243 \mathrm{~km} .{ }^{2}\right)$; the white population is approximately 18,000 , of whom about one third are non-miners. There are four major gold-mines in the area, the vast majority of whose workers live in the town and not on the mine properties.

It is a young town, dating from the end of the Second World War. Economic factors that have drawn the population to the town have probably resulted in selecting a high proportion of experienced miners with appreciable length of service elsewhere -in general the fitter people and those with initiative. There is no reason to believe that the results of a survey would be affected by migration of disabled miners (or non-miners) into the community. An important proportion of the men are on shift work, including night shift work.

Air pollution is low in the town; there are only two coal-burning boilers. Smoke from coal burning in the African village, which is seven miles from the town, is borne by the prevailing winds away from the town.

Before the survey was started a publicity brochure incorporating a fairly detailed explanation of its purposes and the procedures to be applied was delivered to every house in the town through the good services of the Town Council which gave the project its full public support.

The survey was carried out from the beginning of February, 1962 to the end of April, 1963. The winters are fairly warm, sunny, and dry by day, though cold at night. The summer is interspersed with thunderstorms. The annual rainfall is about 25 inches $(63.5 \mathrm{~cm}$.).

The Sample Every third house was visited and all men over the age of 35 were interviewed. The whole survey was conducted by one investigator who is a medically orientated mine hygiene officer. If the men in any house refused to co-operate a neighbouring house was taken. This did not happen often-in fact there were only seven refusals. The survey was limited to white Caucasian men.

Eight hundred and twenty-seven men over 35 were interviewed, of whom $562(68 \%)$ had been exposed to dust and $265(32 \%)$ had never been so exposed. A person who had worked in a scheduled dusty area on a mine was classified as 'exposed to dust' however short the period.

\section{Questionnaire on Respiratory Symptoms}

The long questionnaire approved by the Committee on the Aetiology of Chronic Bronchitis of the Medical Research Council of Great Britain (196I) was adapted as follows: (a) the section on nasal catarrh was deleted; and $(b)$ a section on allergic history, both personal and in blood relations, was added.

Neither of these nor other minor changes affect the matter to be presented and discussed in this paper.

Since well over half the population sample were Afrikaans-speaking and since it was considered important to put the questions in the subject's native language, the questions were all translated. Great care was used in the translation to reflect as accurately as possible the correct nuance of the question. The investigator who carried out the survey was himself fluent in both languages.

No clinical examination was done. Certain simple tests of lung function were carried out on the whole sample, the results of which will be discussed in a separate paper (Sluis-Cremer, Walters, and Sichel, this journal, p. 13).

Every person was given a universal container for the measurement of a one-hour sample of sputum produced immediately after rising; this was measured by the interviewer. 


\section{Characteristics of the Samples}

The 562 persons in the dust-exposed group and the 265 without dust exposure are compared as far as age, standing and sitting heights, weight, and smoking habits are concerned.

Table I shows the quinquennial age distribution of the two groups. It will be noted that the dustexposed group are slightly younger, average age 44.9 years, than the group without exposure whose average age is 46.5 years.

TABLE I

Age Distribution

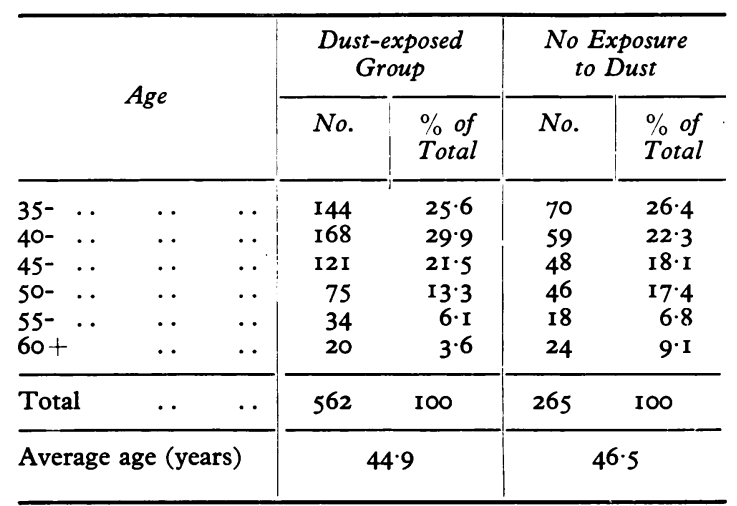

Tables II and III give the distribution of the standing and sitting heights of the subjects in the two groups. Those in the dust-exposed group are slightly shorter (standing height $69 \cdot \mathrm{I}$ in. (I75 cm.)) than those in the non-dust-exposed group (standing height 69.5 in. ( $176 \mathrm{~cm}$.) ).

There is no difference in the sitting heights between the two groups, each being $34 \cdot 8$ in. $(57 \mathrm{~cm}$.) (Tables II and III).

The weight distribution is presented in Table IV; persons in the dust-exposed group are on average $4.5 \mathrm{lb}$. (2 kg.) heavier than those in the non-dustexposed group.

In any such study as this, characterization of the smoking habits of the persons in the two groups is of the greatest importance.

Table $\mathrm{V}$ gives the smoking status of the men in the two groups, and Table VI gives quantitative detail of the smoking habits of the present smokers.

Table $\mathrm{V}$ shows that there are more present smokers and fewer non-smokers in the dust-exposed group. The number of persons who have given up smoking is similar in the two groups.

The data tabulated in Table VI were derived as follows. Respondents were asked tc state the
TABLE II

Distribution of Standing Height

\begin{tabular}{|c|c|c|c|c|c|c|}
\hline \multicolumn{3}{|c|}{$\begin{array}{c}\text { Standing } \\
\text { Height }\end{array}$} & \multicolumn{2}{|c|}{$\begin{array}{c}\text { Dust-exposed } \\
\text { Group }\end{array}$} & \multicolumn{2}{|c|}{$\begin{array}{c}\text { No Exposure } \\
\text { to Dust }\end{array}$} \\
\hline (in.) & \multicolumn{2}{|l|}{$(\mathrm{cm})}$. & No. & $\begin{array}{l}\% \text { of } \\
\text { Total }\end{array}$ & No. & $\begin{array}{l}\% \text { of } \\
\text { Total }\end{array}$ \\
\hline $6 I$ & 154 & .. & I & 0.2 & 0 & 0.0 \\
\hline 62 & I 57 & . & 0 & 0.0 & 2 & 0.8 \\
\hline 63 & 160 & $\ldots$ & 5 & 0.9 & I & 0.4 \\
\hline 64 & 162 & . & 18 & $3 \cdot 2$ & 7 & $2 \cdot 6$ \\
\hline 65 & 165 & . & 13 & $2 \cdot 3$ & 8 & 3.0 \\
\hline 66 & 167 & . & 40 & $7 \cdot 1$ & 9 & $3 \cdot 4$ \\
\hline 67 & 170 & $\ldots$ & 57 & 10.1 & 21 & $7 \cdot 9$ \\
\hline 68 & 172 & . & 88 & 15.7 & $4 I$ & 15.5 \\
\hline 69 & 175 & $\ldots$ & 73 & 13.0 & 27 & 10.2 \\
\hline 70 & I77 & . & 104 & 18.5 & 60 & $22 \cdot 6$ \\
\hline 71 & 180 & . & 90 & 16.0 & 35 & 13.2 \\
\hline 72 & 182 & $\ldots$ & 30 & $5 \cdot 3$ & 27 & 10.2 \\
\hline 73 & 185 & . & 22 & 3.9 & 15 & $5 \cdot 7$ \\
\hline 74 & 187 & . & 15 & $2 \cdot 7$ & 6 & $2 \cdot 3$ \\
\hline 75 & 190 & . & 4 & 0.7 & 3 & $I \cdot I$ \\
\hline 76 & I93 & . & 2 & 0.4 & 3 & $I \cdot I$ \\
\hline Total & . & . & 562 & 100 & 265 & 100 \\
\hline $\begin{array}{c}\text { Average } \\
\text { (in.) } \\
\text { (cm.) }\end{array}$ & $\begin{array}{c}\text { ight } \\
\text {. } \\
\text {. }\end{array}$ & $\begin{array}{l}\cdots \\
\cdots\end{array}$ & \multicolumn{2}{|c|}{$69 \cdot 1$} & \multicolumn{2}{|c|}{$\begin{array}{l}69 \cdot 5 \\
176\end{array}$} \\
\hline
\end{tabular}

TABLE III

Distribution of Sitting Height

\begin{tabular}{|c|c|c|c|c|c|c|}
\hline \multicolumn{3}{|c|}{ Sitting Height } & \multicolumn{2}{|c|}{$\begin{array}{c}\text { Dust-exposed } \\
\text { Group }\end{array}$} & \multicolumn{2}{|c|}{$\begin{array}{c}\text { No Exposure } \\
\text { to Dust }\end{array}$} \\
\hline (in.) & \multicolumn{2}{|c|}{$(\mathrm{cm})}$. & No. & $\begin{array}{l}\% \text { of } \\
\text { Total }\end{array}$ & No. & $\begin{array}{l}\% \text { of } \\
\text { Total }\end{array}$ \\
\hline 31 & 78 & .. & I & 0.2 & 4 & I. 5 \\
\hline 32 & $8 I$ & $\ldots$ & 19 & 3.4 & 8 & 30 \\
\hline 33 & 83 & $\ldots$ & 57 & IO. I & 22 & $8 \cdot 4$ \\
\hline 34 & 86 & $\ldots$ & 164 & $29 \cdot 2$ & 78 & $29 \cdot 7$ \\
\hline 35 & 88 & . & 158 & $28 \cdot 1$ & 68 & 25.9 \\
\hline 36 & 9 I & .. & II 4 & $20 \cdot 3$ & 52 & 19.8 \\
\hline 37 & 93 & $\ldots$ & 42 & $7 \cdot 5$ & 25 & 9.5 \\
\hline 38 & 96 & . & 6 & $\mathbf{I} \cdot \mathbf{I}$ & 4 & $I \cdot 5$ \\
\hline 39 & 99 & . & I & 0.2 & 2 & 0.8 \\
\hline Tota & 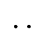 & .. & 562 & 100 & $263^{1}$ & 100 \\
\hline \multicolumn{2}{|c|}{$\begin{array}{r}\text { Average (in.) } \\
\text { (cm.) }\end{array}$} & $\begin{array}{l}. . \\
. .\end{array}$ & \multicolumn{2}{|c|}{$\begin{array}{l}34 \cdot 8 \\
57\end{array}$} & \multicolumn{2}{|c|}{$34 \cdot 8$} \\
\hline
\end{tabular}

${ }^{1}$ In two cases in the non-dust-exposed group no measurement was made. 
TABLE IV

Weight Distribution

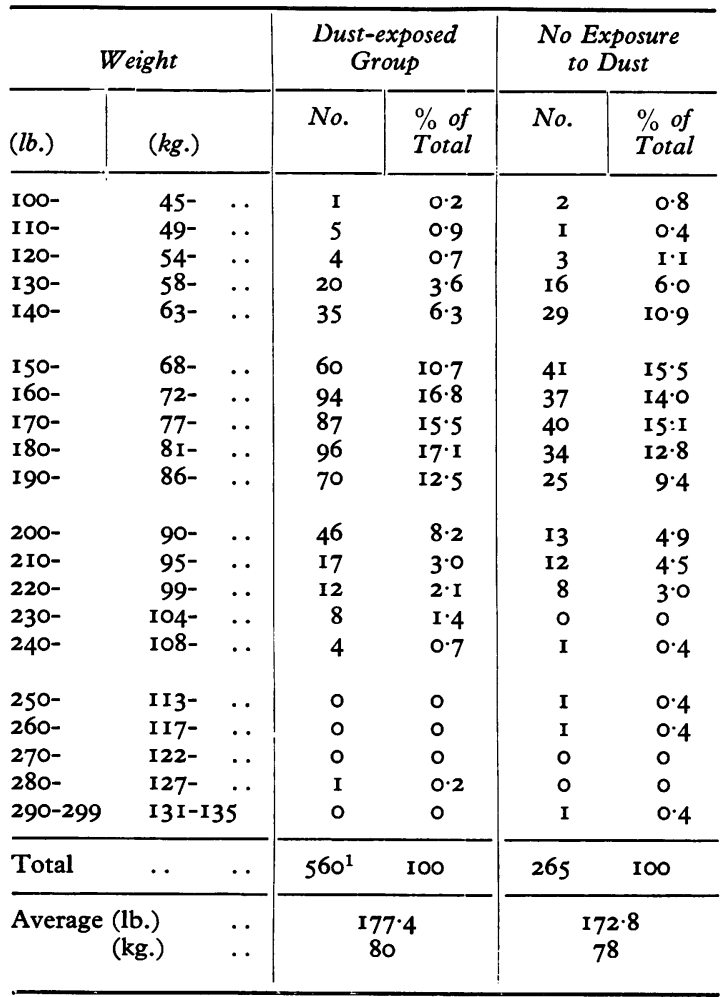

1 In two cases in the dust-exposed group no measurement was made.

TABLE V

SMOKING HABITS

\begin{tabular}{|c|c|c|c|c|}
\hline \multirow{2}{*}{ Smoking Status } & \multicolumn{2}{|c|}{$\begin{array}{l}\text { Dust-exposed } \\
\text { Group }\end{array}$} & \multicolumn{2}{|c|}{$\begin{array}{l}\text { No Exposure } \\
\text { to Dust }\end{array}$} \\
\hline & No. & $\begin{array}{l}\% \text { of } \\
\text { Total }\end{array}$ & No. & $\begin{array}{l}\% \text { of } \\
\text { Total }\end{array}$ \\
\hline $\begin{array}{l}\text { Non-smokers } \\
\text { Past smokers } \\
\text { Present smokers }\end{array}$ & $\begin{array}{r}16 \\
107 \\
394\end{array}$ & $\begin{array}{l}10 \cdot 9 \\
19 \cdot 1 \\
70 \cdot 0\end{array}$ & $\begin{array}{r}45 \\
59 \\
161\end{array}$ & $\begin{array}{l}17 \cdot 0 \\
22 \cdot 3 \\
60 \cdot 7\end{array}$ \\
\hline Total & 562 & 100 & 265 & 100 \\
\hline
\end{tabular}

number of cigarettes smoked per day, the number of cigars consumed per week, or the ounces of tobacco used per week in pipes or for hand-rolled cigarettes. Many persons were mixed smokers, especially those smoking pipes and cigarettes. To find a common denominator, all types of tobacco were converted into grammes as follows:-
One cigarette
I $\mathrm{g}$.
One ounce tobacco $\quad 28 \mathrm{~g}$.
One small cigar
$2 \mathrm{~g}$.
One large cigar
$5 \mathrm{~g}$.

Table $\mathrm{V}$ shows that, although there are more 'present smokers' in the dust-exposed group, the quantitative distribution of smoking (Table VI) in the two groups is similar and the 'present smokers' average daily consumption in the dust-exposed group exceeds that in the non-dust-exposed group by a very small margin of $\mathrm{I} \cdot 5$ cigarettes daily, which is not significant at the $5 \%$ probability level.

TABLE VI

SMOKING HABITS BY AMOUNT SMOKED

\begin{tabular}{|c|c|c|c|c|c|c|}
\hline \multirow{2}{*}{\multicolumn{3}{|c|}{$\begin{array}{c}\text { Quantity of Current } \\
\text { Smoking } \\
(g .)\end{array}$}} & \multicolumn{2}{|c|}{$\begin{array}{l}\text { Dust-exposed } \\
\text { Group }\end{array}$} & \multicolumn{2}{|c|}{$\begin{array}{c}\text { No Exposure } \\
\text { to Dust }\end{array}$} \\
\hline & & & No. & $\%$ of & No. & $\%$ of \\
\hline Nil & . & . & I68 & $29 \cdot 9$ & 104 & $39 \cdot 2$ \\
\hline$I-4$ & . & . . & 7 & $\mathbf{I} \cdot \mathbf{2}$ & 6 & $2 \cdot 3$ \\
\hline $5-14$ & . . & .. & 47 & $8 \cdot 4$ & 24 & $9 \cdot I$ \\
\hline $15-24$ & . & . & I75 & $3 I \cdot I$ & 76 & 28.7 \\
\hline $25-34$ & $\cdots$ & . & 104 & 18.5 & 32 & $12 \cdot I$ \\
\hline $35-44$ & . & .. & 45 & $8 \cdot 0$ & I6 & $6 \cdot 0$ \\
\hline $45-54$ & .. & .. & 6 & $\mathbf{I} \cdot \mathbf{I}$ & 2 & 0.8 \\
\hline $55+$ & .. & .. & 10 & I. 8 & 5 & I.9 \\
\hline Total & . & .. & 562 & 100 & 265 & 100 \\
\hline \multicolumn{3}{|c|}{$\begin{array}{c}\text { Average consumption } \\
\text { of smokers (g.) } \ldots\end{array}$} & \multicolumn{2}{|c|}{$24 \cdot 8$} & \multicolumn{2}{|c|}{$23 \cdot 3$} \\
\hline
\end{tabular}

The non-dust-exposed group were not clinically examined or radiographed. The group may therefore contain individuals with pulmonary tuberculosis, bronchiectasis, mitral stenosis, and other conditions that may present as the chronic bronchitis syndrome. It is thought that the numbers of these must be so small as to be statistically insignificant. The prevalence of pulmonary tuberculosis found by mass surveys in the European population of the city of Johannesburg in recent years is about four per I0,000.

In the dust-exposed group five persons had been certified as suffering from pulmonary tuberculosis. As all these had only minimal lesions with no cavitation and had received full treatment, it was considered that the lesions would be unlikely to contribute significantly to the degree of cough and phlegm, and they were accordingly retained in the sample. 
The dust-exposed group is subjected to a preemployment examination, including radiological examination on a large film, and subsequently compulsory annual radiological and clinical examinations are done. The number of cases of lung and heart disease in this group that might contribute to the symptoms of cough and phlegm is certainly reduced by this procedure compared with the nondust-exposed group.

Orie, Sluiter, Vries, and Witkop (1960) believe that the development of chronic bronchitis is greatly facilitated by inheriting an 'asthmatic' constitution. Questions relating to a history of certain allergic conditions in the respondent himself or in blood relations were asked. Answers to questions relating to hay fever, asthma, urticaria, eczema, and rash resulting from medicines were available in all persons interviewed in the survey. A positive answer to one of these questions, concerning either the respondent himself or blood relations, was obtained in $60.7 \%$ of the dust-exposed group and in $55.1 \%$ of the non-dust-exposed group. These two percentages are not significantly different at the $5 \%$ level of probability.

Twenty-seven persons in the dust-exposed group had radiological signs of silicosis. A series of statistical tests was carried out to ascertain whether this group differed from the non-silicotic members of the dust-exposed group in age, smoking habits, or incidence of bronchitis. The average age of the silicotics was 49.5 (S.D. 7.4) years and of the nonsilicotic, dust-exposed group $44 \cdot 7$ (S.D. 7.2) years. A comparison of the smoking habits of the above two groups is given in Table VII and shows that the differences are not significant $\left(\chi^{2}=3.591\right.$ with 3 degrees of freedom). There was no significant difference in the incidence of chronic bronchitis in the two groups (this is discussed later). The silicotics were therefore retained in the dust-exposed sample.

\section{TABLE VII}

SMOKING Habits of Silicotics and Non-silicotics IN THE DUST-EXPOSED GROUP

\begin{tabular}{|c|c|c|}
\hline Smoking Habit & Silicotic & Non-silicotic \\
\hline $\begin{array}{l}\text { Non- and ex-smokers } \\
\text { Light (1-14 g.) } \\
\text { Medium }(15-24 \text { g.) } \\
\text { Heavy (25 g. }+ \text {. }\end{array}$ & $\begin{array}{r}12(44.5 \%) \\
3(11 \cdot 1 \%) \\
5(18.5 \%) \\
7(25.9 \%)\end{array}$ & $\begin{array}{l}156(29.2 \%) \\
51(9.5 \%) \\
170(31.8 \%) \\
158(29.5 \%)\end{array}$ \\
\hline Total & $27(100 \%)$ & $535(100 \%)$ \\
\hline
\end{tabular}

\section{Incidence of Chronic Bronchitis}

Two definitions of chronic bronchitis were used to examine the factors that affect the prevalence of the condition.

The first (Higgins, 1957; Higgins et al., 1959) required positive responses to questions $I$ or 3,5 , 6 or 8 , and 10 (definition 1 ).

The relevant questions are as follows:-

I. Do you usually cough first thing in the morning in the winter? (on getting up in the case of night shift workers)

3. Do you usually cough during the day or at night in the winter? (Ignore an occasional cough-six or less.)

5. If there is a positive answer to (I) or (3) ask: Do you cough like this on most days for as much as three months or more each year?

6. Do you usually bring up any phlegm from your chest first thing in the morning in the winter ? (on first getting up in the case of night shift workers)

8. Do you bring up any phlegm from your chest during the day or at night in the winter? (Accept twice or more.)

Io. If there is a positive answer to (6) or (8) ask: Do you bring up phlegm like this on most days for as much as three months each year?

The chronic bronchitis rates in accordance with this definition are given in Table VIII.

TABLE VIII

InCidence of Chronic Bronchitis (Definition I)

\begin{tabular}{ll|r|r|r}
\hline & $\begin{array}{c}\text { Chronic } \\
\text { Bronchitis }\end{array}$ & $\begin{array}{c}\text { No } \\
\text { Bronchitis }\end{array}$ & Total \\
\hline Dust-exposed & $\cdots$ & $221(39 \cdot 3 \%)$ & $341(60 \cdot 7 \%)$ & 562 \\
No exposure &. & $52(19.6 \%)$ & $213(80 \cdot 4 \%)$ & 265 \\
\hline
\end{tabular}

It will be seen that the chronic bronchitis rate for the dust-exposed group is twice that for the group without dust exposure.

The influence of age on the rates of chronic bronchitis is shown in Table IX.

It will be noted that the dust-exposed group show a markedly higher rate of chronic bronchitis in all age groups. It will also be seen that there are, as expected, steadily increasing rates with age in the non-dust-exposed group but that this is much less marked in the dust-exposed group.

Table $\mathrm{X}$ is a bivariate table showing the incidence of chronic bronchitis for different service and age categories.

Those with less than one year's service show an incidence (14.3\%) similar to that found in the nondust-exposed group (19.6\%).

Service has a stronger influence on chronic bronchitis rate than age, and near maximal rates are often reached in the I I-I5 years' service group. 
TABLE IX

InCIDence of Chronic Bronchitis By Age (Definition I)

\begin{tabular}{|c|c|c|c|c|c|c|}
\hline \multirow[b]{2}{*}{$\begin{array}{c}\text { Age } \\
\text { (years) }\end{array}$} & \multicolumn{3}{|c|}{ Dust-exposed Group } & \multicolumn{3}{|c|}{ No Exposure to Dust } \\
\hline & $\begin{array}{c}\text { No. with } \\
\text { Chronic } \\
\text { Bronch- } \\
\text { itis }\end{array}$ & $\begin{array}{c}\text { Total } \\
\text { No. in } \\
\text { Group }\end{array}$ & $\%$ & $\begin{array}{c}\text { No. with } \\
\text { Chronic } \\
\text { Bronch- } \\
\quad \text { itis }\end{array}$ & $\begin{array}{c}\text { Total } \\
\text { No. in } \\
\text { Group }\end{array}$ & $\%$ \\
\hline $35-\ldots$ & 52 & I44 & $36 \cdot 1$ & 8 & 70 & II. 4 \\
\hline $40-\ldots$ & 70 & 168 & $4 \mathrm{I} \cdot 7$ & I I & 59 & 18.6 \\
\hline $45-\ldots$ & 42 & I2I & 34.7 & IO & 48 & 20.8 \\
\hline $50-\ldots$ & 33 & 75 & 44.0 & 12 & 46 & $26 \cdot I$ \\
\hline $55-\ldots$ & 16 & 34 & $47 \cdot 1$ & 4 & 18 & $22 \cdot 2$ \\
\hline $60+$ & 8 & 20 & $40 \cdot 0$ & 7 & 24 & $29 \cdot 2$ \\
\hline Total & $22 \mathrm{I}$ & 562 & 39.3 & 52 & 265 & $19 \cdot 6$ \\
\hline
\end{tabular}

All previous studies have shown that smoking habits have an overwhelming effect on chronic bronchitis rates.

Table XI gives the percentages of present smokers among those with and without chronic bronchitis for both the dust-exposed and non-dust-exposed groups.

The percentage of persons smoking at present is very significantly higher in the group with chronic bronchitis $(P<0.01)$. This applies to both the dust-exposed and non-dust-exposed groups.

Table XII gives the total tobacco consumption per day for present smokers. For this purpose all types of tobacco used were converted by means of the conversion table previously outlined into grammes of tobacco per day. The data are shown

TABLE X

Incidence of Chronic Bronchitis according to Length of Service and Age

\begin{tabular}{|c|c|c|c|c|c|c|c|c|c|}
\hline \multirow{2}{*}{$\begin{array}{c}\text { Age at Time } \\
\text { of Survey (yrs.) }\end{array}$} & \multicolumn{9}{|c|}{ Length of Service in Dusty Atmosphere (yrs.) } \\
\hline & $<$ I & $1-5$ & 6-10 & II-15 & $16-20$ & $21-25$ & $26-30$ & $3 \mathbf{I}+$ & Total \\
\hline $35-$ & $\begin{array}{l}0.0 \% \\
(4)\end{array}$ & $\begin{array}{c}30 \cdot 8 \% \\
(26)\end{array}$ & $\begin{array}{c}27.6 \% \\
(29)\end{array}$ & $\begin{array}{c}48 \cdot 6 \% \\
(35)\end{array}$ & $\begin{array}{c}32 \cdot 6 \% \\
(43)\end{array}$ & $\begin{array}{c}71 \cdot 4 \% \\
(7)\end{array}$ & 一 & - & $\begin{array}{l}36 \cdot 1 \% \\
(144)\end{array}$ \\
\hline 40- & $\begin{array}{l}0.0 \% \\
\text { (I) }\end{array}$ & $\begin{array}{c}33.3 \% \\
\text { (18) }\end{array}$ & $\begin{array}{c}21 \cdot 4 \% \\
\text { (14) }\end{array}$ & $\begin{array}{l}60 \cdot 7 \% \\
(28)\end{array}$ & $\begin{array}{c}45 \cdot 2 \% \\
(42)\end{array}$ & $\begin{array}{c}40 \cdot 7 \% \\
(59)\end{array}$ & $\begin{array}{c}16 \cdot 6 \% \\
(6)\end{array}$ & - & $\begin{array}{l}41 \cdot 7 \% \\
(168)\end{array}$ \\
\hline $45-$ & $\begin{array}{l}0.0 \% \\
\text { (I) }\end{array}$ & $\begin{array}{l}16.7 \% \\
\text { (I2) }\end{array}$ & $\begin{array}{l}\text { I I. I \% } \\
\text { (9) }\end{array}$ & $\begin{array}{c}56 \cdot 2 \% \\
(16)\end{array}$ & $\begin{array}{c}50 \cdot 0 \% \\
\text { (14) }\end{array}$ & $\begin{array}{c}26 \cdot 3 \% \\
(38)\end{array}$ & $\begin{array}{c}4 \mathrm{I} \cdot 4 \% \\
(29)\end{array}$ & $\begin{array}{c}50.0 \% \\
\text { (2) }\end{array}$ & $\begin{array}{c}34: 7 \% \\
(121)\end{array}$ \\
\hline $50-$ & $\begin{array}{c}100.0 \% \\
\text { (I) }\end{array}$ & $\begin{array}{c}30 \cdot 8 \% \\
\text { (13) }\end{array}$ & $\begin{array}{c}33 \cdot 3 \% \\
(6)\end{array}$ & $\begin{array}{c}37.5 \% \\
(8)\end{array}$ & $\begin{array}{c}54.5 \% \\
\text { (II) }\end{array}$ & $\begin{array}{c}55 \cdot 6 \% \\
(9)\end{array}$ & $\begin{array}{c}43 \cdot 5 \% \\
(23)\end{array}$ & $\begin{array}{c}50 \cdot 0 \% \\
(4)\end{array}$ & $\begin{array}{c}44.0 \% \\
(75)\end{array}$ \\
\hline $55+$ & - & $\begin{array}{c}14.3 \% \\
(7)\end{array}$ & $\begin{array}{l}0.0 \% \\
\text { (I) }\end{array}$ & $\begin{array}{l}0.0 \% \\
(4)\end{array}$ & $\begin{array}{c}50 \cdot 0 \% \\
(8)\end{array}$ & $\begin{array}{l}25 \cdot 0 \% \\
(4)\end{array}$ & $\begin{array}{c}62: 5 \% \\
(8)\end{array}$ & $\begin{array}{c}59 \cdot 1 \% \\
(22)\end{array}$ & $\begin{array}{c}44 \cdot 4 \% \\
(54)\end{array}$ \\
\hline Total & $\begin{array}{c}14.3 \% \\
(7)\end{array}$ & $\begin{array}{c}27 \cdot 6 \% \\
(76)\end{array}$ & $\begin{array}{c}23.6 \% \\
(59)\end{array}$ & $\begin{array}{c}50.5 \% \\
(91)\end{array}$ & $\begin{array}{l}42 \cdot 4 \% \\
(118)\end{array}$ & $\begin{array}{l}38.5 \% \\
(117)\end{array}$ & $\begin{array}{c}42 \cdot 4 \% \\
(66)\end{array}$ & $\begin{array}{l}57 \cdot 1 \% \\
(28)\end{array}$ & $\begin{array}{c}39 \cdot 3 \% \\
(562)\end{array}$ \\
\hline
\end{tabular}

Figures in parentheses indicate no. in the sample.

TABLE XI

Smoking Status and Chronic Bronchitis

\begin{tabular}{|c|c|c|c|c|c|c|c|c|c|}
\hline \multicolumn{7}{|c|}{ Smoking Status } & \multirow{2}{*}{$\begin{array}{c}\text { Chronic Bronchitis } \\
199(90.0 \%) \\
22(10.0 \%)\end{array}$} & \multirow{2}{*}{$\begin{array}{l}\text { No Bronchitis } \\
\\
195(57 \cdot 2 \%) \\
146(42 \cdot 8 \%)\end{array}$} & \multirow{2}{*}{$\begin{array}{c}\text { Total } \\
\\
394(70 \cdot 1 \%) \\
168(29 \cdot 9 \%)\end{array}$} \\
\hline $\begin{array}{l}\text { Dust-exposed group } \\
\text { Present smoker } \\
\text { Non- or ex-smoker }\end{array}$ & $\ddot{*}$ & $\ddot{*}$ & $\ddot{*}$ & $\cdots$ & $\ddot{*}$ & $\cdots$ & & & \\
\hline Total & $\cdots$ & $\cdots$ & $\cdots$ & $\cdots$ & . & $\cdots$ & $221(100 \%)$ & $341(100 \%)$ & $562(100 \%)$ \\
\hline $\begin{array}{l}\text { Non-dust-exposed grou } \\
\text { Present smoker } \\
\text { Non- or ex-smoker }\end{array}$ & $\begin{array}{l}\text { up } \\
\cdots \\
\cdots\end{array}$ & $\begin{array}{l}\cdots \\
\cdots\end{array}$ & $\cdots$ & $\cdots$ & $\cdots$ & $\cdots$ & $\begin{array}{r}45(86.5 \%) \\
7(13.5 \%)\end{array}$ & $\begin{array}{r}\text { I I6 }(54.5 \%) \\
97(45.5 \%)\end{array}$ & $\begin{array}{l}\text { I6I }(60 \cdot 8 \%) \\
104(39 \cdot 2 \%)\end{array}$ \\
\hline Total & $\cdots$ & $\cdots$ & $\cdots$ & $\cdots$ & $\cdots$ & $\cdots$ & $52(100 \%)$ & $213(100 \%)$ & $265(100 \%)$ \\
\hline
\end{tabular}


TABLE XII

InCidence of Chronic Bronchitis (Definition I) By Tobacco SMoked

\begin{tabular}{|c|c|c|c|c|c|c|c|c|c|c|c|}
\hline & \multirow{2}{*}{\multicolumn{2}{|c|}{$\begin{array}{l}\text { Tobacco } \\
\text { (g./day) }\end{array}$}} & & \multicolumn{4}{|c|}{ Dust-exposed Group } & \multicolumn{4}{|c|}{ No Exposure to Dust } \\
\hline & & & & Bronchitis & $\begin{array}{c}\text { No } \\
\text { Bronchitis }\end{array}$ & Total & $\begin{array}{c}\text { Bronchitis } \\
(\% \text { of total })\end{array}$ & Bronchitis & $\begin{array}{c}\text { No } \\
\text { Bronchitis }\end{array}$ & Total & $\begin{array}{l}\text { Bronchitis } \\
(\% \text { of total })\end{array}$ \\
\hline \multicolumn{3}{|c|}{ Non- and ex-smokers } & . & 22 & 146 & 168 & I3. I & 7 & 97 & 104 & $6 \cdot 7$ \\
\hline$I-4 \cdots$ & . & $\cdots$ & . & - & 7 & 7 & 0 & 2 & 4 & 6 & $33 \cdot 3$ \\
\hline $5-14$ & . & . & . & 23 & 24 & 47 & $48 \cdot 9$ & 6 & 18 & 24 & $25 \cdot 0$ \\
\hline $15-24$ & . & . & . & 84 & 91 & 175 & $48 \cdot 0$ & 19 & 57 & 76 & $25 \cdot 0$ \\
\hline $25-34$ & . & . & . & 62 & 42 & 104 & $59 \cdot 6$ & 7 & 25 & 32 & $2 \mathrm{I} \cdot 9$ \\
\hline $35-44$ & . & . & . & $2 \mathbf{I}$ & 24 & 45 & $46 \cdot 7$ & 6 & Io & 16 & $37 \cdot 5$ \\
\hline $45-54$ & . & . & . & 4 & 2 & 6 & $66 \cdot 7$ & 2 & 0 & 2 & $100 \cdot 0$ \\
\hline $55+$ & $\cdots$ & . & $\cdots$ & 5 & 5 & IO & $50 \cdot 0$ & 3 & 2 & 5 & $60 \cdot 0$ \\
\hline Total & . & . & . & $22 I$ & $34 I$ & 562 & $39 \cdot 3$ & 52 & 213 & 265 & $19 \cdot 6$ \\
\hline \multicolumn{3}{|c|}{ Average (g./day) $\ldots$} & . & $25 \cdot 3$ & $23 \cdot 8$ & $24 \cdot 5$ & & 26 & 22 & $23 \cdot 1$ & \\
\hline
\end{tabular}

separately for the dust-exposed and non-dustexposed groups. The average weights in grammes of daily tobacco consumption for each individual group are also given.

There is a trend for the incidence of chronic bronchitis to increase with tobacco consumption in the non-dust-exposed group. This trend is distinctly less evident in the dust-exposed group.

Of importance is the clear excess in the incidence of chronic bronchitis in the dust-exposed compared with the non-dust-exposed group for every class of tobacco consumption where an adequate sample was obtained. It is clear that some factor is operative in the dust-exposed group, increasing the incidence of chronic bronchitis over and above the effect of smoking.

It is interesting to note that the major increase in the incidence of chronic bronchitis occurs between the 'no smoking' and 'light smoking' (5-14 g./day) groups. The very fact that one smokes at all is more important in the causation of bronchitis than the actual quantity of tobacco consumed per day.

The interaction between smoking and mining is also clearly discernible in Table XIII.

The differences in chronic bronchitis rate between the dust-exposed and non-dust-exposed groups are highly significant for present smukers (at $0.01 \%$ level of probability) and almost significant at the $5 \%$ probability level for past smokers. The difference for non-smokers is not significant at the $5 \%$ level of probability.

A more stringent criterion for defining chronic bronchitis was then applied. This demands an affirmative response to the same questions as were used for definition I and, in addition, a positive

\section{TABLE XIII}

Chronic Bronchitis (Definition I) in Non, Past, and PRESENT SMOKERS

\begin{tabular}{|c|c|c|c|c|}
\hline & $\begin{array}{c}\text { Non- } \\
\text { Smokers }\end{array}$ & $\begin{array}{c}\text { Past } \\
\text { Smokers }\end{array}$ & $\begin{array}{l}\text { Present } \\
\text { Smokers }\end{array}$ & Total \\
\hline $\begin{array}{l}\text { Dust-exposed } \\
\text { Chronic bronchitis } \\
\text { No bronchitis .. }\end{array}$ & $\begin{array}{r}5 \\
56\end{array}$ & $\begin{array}{l}17 \\
90\end{array}$ & $\begin{array}{l}199 \\
195\end{array}$ & $\begin{array}{l}221 \\
34 I\end{array}$ \\
\hline $\begin{array}{l}\text { Total .. } \\
\text { Bronchitis (\%) }\end{array}$ & $\begin{array}{l}61 \\
8 \cdot 2\end{array}$ & $\begin{array}{l}107 \\
15.9\end{array}$ & $\begin{array}{l}394 \\
50.5\end{array}$ & $\begin{array}{l}562 \\
39 \cdot 3\end{array}$ \\
\hline $\begin{array}{l}\text { No exposure to dust } \\
\text { Chronic bronchitis } \\
\text { No bronchitis .. }\end{array}$ & $\begin{array}{r}3 \\
42\end{array}$ & $\begin{array}{r}4 \\
55\end{array}$ & $\begin{array}{r}45 \\
116\end{array}$ & $\begin{array}{r}52 \\
213\end{array}$ \\
\hline $\begin{array}{l}\text { Total . } \\
\text { Bronchitis (\%) }\end{array}$ & $\begin{array}{l}45 \\
6 \cdot 7\end{array}$ & $\begin{array}{l}59 \\
6.8\end{array}$ & $\begin{array}{l}161 \\
28 \cdot 0\end{array}$ & $\begin{array}{l}265 \\
19.6\end{array}$ \\
\hline
\end{tabular}

response to the following question concerning chest illness:-

During the past three years have you had any chest illness which has kept you off work, indoors at home, or in bed?

By this means a more serious form of chronic bronchitis is defined (definition II) (Higgins, 1957).

A highly significant difference in the incidence of chronic bronchitis between the dust-exposed and non-dust-exposed groups is again obtained $\left(\chi^{2}=\right.$ 9.36; I degree of freedom) as shown in Table XIV.

The effect of smoking and of age on the prevalence of this more serious form of chronic bronchitis is shown in Table XV.

To determine whether belonging to the dustexposed group is a further hazard in the chance of 
TABLE XIV

INCIDENCE OF Chronic Bronchitis (Definition II)

\begin{tabular}{|c|c|c|c|}
\hline Group & $\begin{array}{l}\text { Chronic } \\
\text { Bronchitis }\end{array}$ & $\begin{array}{l}\text { No } \\
\text { Bronchitis }\end{array}$ & Total \\
\hline $\begin{array}{l}\text { Dust-exposed } \\
\text { No exposure to dust }\end{array}$ & $\begin{array}{l}59(10.5 \%) \\
\text { II }(4.2 \%)\end{array}$ & $\begin{array}{l}503(89.5 \%) \\
254(95.8 \%)\end{array}$ & $\begin{array}{l}562 \\
265\end{array}$ \\
\hline Total & 70 & 757 & 827 \\
\hline
\end{tabular}

getting chronic bronchitis as defined by definition II, Table XVI was constructed, age (in decennials) and smoking category being standardized. The table shows that there is such an extra hazard. For the 35-44 age group the incidence of chronic bronchitis is a good deal higher in the dust-exposed group for all smoking categories. These differences, at the $5 \%$ level of probability, are significant. For the 45-54 age group the difference is not as marked but is still considerable in three out of four smoking groups; the pooled smoking groups are significantly higher for the dust-exposed group at the $5 \%$ level of probability. The same applies to the age group over 55 where the difference has become less marked but is still important, although no significant difference could be established due to the relatively small number of subjects in the individual smoking categories.

Table XVII shows the incidence of chronic bronchitis in the silicotic and non-silicotic members of the dust-exposed group, as diagnosed by definition I, and Table XVIII as diagnosed by the definition II.

TABLE XV

Chronic Bronchitis (Definition II) Related to Amount Smoked, Dust-exposed and Non-dust-exposed Groups Combined

\begin{tabular}{|c|c|c|c|c|c|c|c|c|c|c|c|c|c|c|c|c|c|}
\hline \multirow{2}{*}{ Age Group } & & \multicolumn{4}{|c|}{ Non- and Ex-smoker } & \multicolumn{4}{|c|}{ Light (I-I4 g./day) } & \multicolumn{4}{|c|}{ Medium (I5-24 g./day) } & \multicolumn{4}{|c|}{ Heavy $(25+g . /$ day $)$} \\
\hline & & $35-$ & $45-$ & $55+$ & Total & $35-$ & $45^{-}$ & $55+$ & Total & $35-$ & $45-$ & $55+$ & Total & $35-$ & $45^{-}$ & $55+$ & Tota \\
\hline $\begin{array}{l}\text { Chronic bronchitis } \\
\text { No bronchitis }\end{array}$ & $\begin{array}{l}\cdots \\
\cdots\end{array}$ & $\begin{array}{r}3 \\
117\end{array}$ & $\begin{array}{r}4 \\
115\end{array}$ & $\begin{array}{r}\mathbf{I} \\
32\end{array}$ & $\begin{array}{r}8 \\
264\end{array}$ & $\begin{array}{r}3 \\
36\end{array}$ & $\begin{array}{r}3 \\
28\end{array}$ & $\begin{array}{r}4 \\
10\end{array}$ & $\begin{array}{l}10 \\
74\end{array}$ & $\begin{array}{r}13 \\
144\end{array}$ & $\begin{array}{r}7 \\
59\end{array}$ & $\begin{array}{r}4 \\
24\end{array}$ & $\begin{array}{r}24 \\
227\end{array}$ & $\begin{array}{r}13 \\
112\end{array}$ & $\begin{array}{l}12 \\
62\end{array}$ & $\begin{array}{r}3 \\
18\end{array}$ & $\begin{array}{r}28 \\
192\end{array}$ \\
\hline $\begin{array}{l}\text { Total .. } \\
\text { Bronchitis (\%) }\end{array}$ & $\begin{array}{l}. . \\
.\end{array}$ & $\begin{array}{l}120 \\
2.5\end{array}$ & $\begin{array}{l}119 \\
3.4\end{array}$ & $\begin{array}{r}33 \\
3\end{array}$ & $\begin{array}{r}272 \\
2.9\end{array}$ & $\begin{array}{l}39 \\
7 \cdot 7\end{array}$ & $\begin{array}{l}31 \\
9 \cdot 7\end{array}$ & $\begin{array}{l}14 \\
28 \cdot 6\end{array}$ & $\begin{array}{l}84 \\
I I \cdot 9\end{array}$ & $\begin{array}{l}157 \\
8.3\end{array}$ & $\begin{array}{l}66 \\
10 \cdot 6\end{array}$ & $\begin{array}{c}28 \\
14 \cdot 3\end{array}$ & $\begin{array}{l}251 \\
9 \cdot 6\end{array}$ & $\begin{array}{l}125 \\
10.4\end{array}$ & $\begin{array}{l}74 \\
16 \cdot 2\end{array}$ & $\begin{array}{l}21 \\
14 \cdot 3\end{array}$ & $\begin{array}{l}220 \\
12 \cdot 7\end{array}$ \\
\hline
\end{tabular}

TABLE XVI

Chronic Bronchitis (Definition II) in Standardized Age and Smoking Categories

\begin{tabular}{|c|c|c|c|c|c|c|c|c|c|c|c|c|c|c|c|}
\hline \multirow[b]{2}{*}{$\begin{array}{l}\text { Smoking } \\
\text { (Present) } \\
\text { (g./day) }\end{array}$} & \multicolumn{5}{|c|}{ Age 35-44 Years } & \multicolumn{5}{|c|}{ Age 45-54 Years } & \multicolumn{5}{|c|}{ Age $55+$ Years } \\
\hline & Nil & $I-I 4$ & $15-24$ & $25+$ & Total & Nil & $I-I 4$ & $15-24$ & $25+$ & Total & $\mathrm{Nil}$ & $I-14$ & $15-24$ & $25+$ & Total \\
\hline $\begin{array}{c}\text { Dust-exposed } \\
\text { Chronic } \\
\text { bronchitis }\end{array}$ & 3 & 3 & 12 & 12 & 30 & 2 & 2 & 6 & II & $2 I$ & $\mathbf{I}$ & 3 & I & 3 & 8 \\
\hline $\begin{array}{l}\text { Total } \\
\text { Bronchitis } \\
\qquad \% \text {. }\end{array}$ & $\begin{array}{l}68 \\
4 \cdot 4\end{array}$ & $\begin{array}{l}30 \\
10.0\end{array}$ & $\begin{array}{l}118 \\
10 \cdot 2\end{array}$ & \begin{tabular}{l|}
96 \\
$\mathbf{1 2} \cdot 5$
\end{tabular} & $\begin{array}{r}312 \\
9.6\end{array}$ & $\begin{array}{l}79 \\
2 \cdot 5\end{array}$ & $\begin{array}{l}17 \\
11 \cdot 8\end{array}$ & $\begin{array}{l}44 \\
13.6\end{array}$ & $\begin{array}{l}56 \\
19 \cdot 6\end{array}$ & $\begin{array}{l}196 \\
10 \cdot 7\end{array}$ & $\begin{array}{l}21 \\
4 \cdot 8\end{array}$ & $\begin{array}{c}7 \\
42 \cdot 8\end{array}$ & $\begin{array}{l}13 \\
7 \cdot 7\end{array}$ & $\begin{array}{l}13 \\
23 \cdot 1\end{array}$ & $\begin{array}{l}54 \\
14 \cdot 8\end{array}$ \\
\hline $\begin{array}{c}\text { No exposure } \\
\text { to dust } \\
\text { Chronic } \\
\text { bronchitis }\end{array}$ & $\circ$ & 0 & $\mathbf{I}$ & I & 2 & 2 & I & I & $\mathbf{I}$ & 5 & o & $\mathbf{I}$ & 3 & o & 4 \\
\hline $\begin{array}{l}\text { Total .. } \\
\text { Bronchitis } \\
\qquad(\%) \quad \cdots\end{array}$ & $\begin{array}{r}52 \\
0\end{array}$ & $\begin{array}{l}9 \\
0\end{array}$ & $\begin{array}{l}39 \\
2 \cdot 6\end{array}$ & $\begin{array}{l}29 \\
3 \cdot 4\end{array}$ & $\begin{array}{r}129 \\
1 \cdot 6\end{array}$ & $\begin{array}{l}40 \\
5 \cdot 0\end{array}$ & $\begin{array}{l}14 \\
7 \cdot 1\end{array}$ & $\begin{array}{l}22 \\
4 \cdot 5\end{array}$ & \begin{tabular}{l|}
18 \\
$5 \cdot 6$
\end{tabular} & $\begin{array}{l}94 \\
5 \cdot 3\end{array}$ & $\begin{array}{l}12 \\
0\end{array}$ & $\begin{array}{c}7 \\
14 \cdot 3\end{array}$ & $\begin{array}{l}15 \\
20 \cdot 0\end{array}$ & $\begin{array}{l}8 \\
0\end{array}$ & $\begin{array}{l}42 \\
9 \cdot 5\end{array}$ \\
\hline
\end{tabular}


TABLE XVII

Chronic Bronchitis (Definition I) IN Silicotics AND NON-SILICOTICS IN THE DUST-EXPOSED GROUP

\begin{tabular}{|c|c|c|c|}
\hline & & Silicotic & Non-silicotic \\
\hline $\begin{array}{l}\text { Chronic bronchitis } \\
\text { No bronchitis.. }\end{array}$ & $\begin{array}{l}\cdots \\
\cdots\end{array}$ & $\begin{array}{l}12(44.4 \%) \\
15(55.6 \%)\end{array}$ & $\begin{array}{l}209(39.1 \%) \\
326(60.9 \%)\end{array}$ \\
\hline Total .. & .. & 27 & 535 \\
\hline
\end{tabular}

$\chi^{2}=0.312$, I degree of freedom: the difference is not significant.

\section{TABLE XVIII}

Chronic Bronchitis (Definition II) in Silicotics and NON-SILICOTICS IN THE DUST-EXPOSED GROUP

\begin{tabular}{|c|c|c|c|}
\hline & & Silicotic & Non-silicotic \\
\hline $\begin{array}{l}\text { Chronic bronchitis } \\
\text { No bronchitis.. }\end{array}$ & $\begin{array}{l}\cdots \\
\cdots\end{array}$ & $\begin{array}{r}4(14.8 \%) \\
23(85 \cdot 2 \%)\end{array}$ & $\begin{array}{r}55(10 \cdot 3 \%) \\
480(89.7 \%)\end{array}$ \\
\hline Total ... & .. & 27 & 535 \\
\hline
\end{tabular}

$\chi^{2}=0.183$, I degree of freedom: the difference is not significant.

\section{Discussion}

Comparability of the Two Groups Of the various personal factors which might influence the prevalence of chronic bronchitis, age, somatotype, personal and family history of allergy, and smoking habits might be considered as important.

Age Table I shows that although the dustexposed group is slightly younger, this is by only $\mathrm{I} \cdot 6$ years in average age. Further, the distribution of ages in quinquennial steps in the groups is comparable. The slightly smaller percentages of older subjects in the dust-exposed group would tend to reduce the prevalence of chronic bronchitis in this group.

Somatotype The dust-exposed group is on average slightly shorter (by 0.4 in.; 10 $\mathrm{mm}$.) and heavier (by $4.6 \mathrm{lb} . ; 2 \mathrm{~kg}$.) than the non-dust-exposed group. The distribution of the different weight groups in the dust-exposed and non-dust-exposed samples is, however, reasonably similar. Even should somatotype be a factor of significance in the prevalence of chronic bronchitis, these differences are not likely to be significant in this regard. The differences are actually less than expected as the dust-exposed population had been subject to a preemployment examination and medical selection.
The average stem height of the two groups is in fact identical.

Personal and Family History of Allergy Of the dust-exposed group $60.7 \%$ and of the non-dustexposed group $55 \cdot 1 \%$ gave affirmative responses to one of the questions directed to eliciting the presence of some aspect of personal or family history of allergy. These differences are not significant at the $5 \%$ probability level.

Smoking Habits There are more current smokers and fewer non-smokers in the dust-exposed group, the incidence of past smoking being very similar in the two groups.

The quantitative distribution (g./day) of the smokers in the two groups is very similar, and there is a negligible difference of $\mathrm{I} \cdot 5 \mathrm{~g}$. between the average daily tobacco consumption of the two groups.

The difference in the percentage of present smokers in the two groups is, however, significant at the $I \%$ probability level and the need for careful standardization for smoking before any difference in prevalence is attributed to other factors, such as dust exposure or exposure to the general underground environment, is obvious.

Awareness of Chest Symptoms Another factor, which may be different in the two groups might be called 'awareness of chest symptoms'. The dustexposed group, apart from being exposed to a preemployment examination, is regularly questioned about chest symptoms including cough, sputum, dyspnoea, wheezing, etc., during the course of a compulsory annual examination. This procedure might well heighten awareness of these symptoms and increase the likelihood of positive answers or increase the grade of symptoms and sharpen the memory for episodes of exacerbation or loss of work due to such exacerbations.

In order to examine this, Table XIX was constructed. This records for each grade of phlegm production, as deduced from the answers in the questionnaire, the actual amount of sputum produced in the first hour after rising. Phlegm was graded as follows. Grade o comprises those who disclaim they produce phlegm on most days for as much as three months a year. Grade I comprises those who claim this but in addition usually bring up phlegm from the chest first thing in the morning or during the day or at night in the winter. Grade 2 comprises those who produce phlegm first thing in the morning and during the day or at night in the winter for as much as three months a year. 
TABLE XIX

Comparison of Symptomatic Phlegm Grade and Measured One-hour Specimen

\begin{tabular}{|c|c|c|c|c|c|c|c|}
\hline \multirow{3}{*}{\multicolumn{2}{|c|}{$\begin{array}{l}\text { Sputum } \\
\text { (ml.) }\end{array}$}} & \multicolumn{6}{|c|}{ Phlegm Grade } \\
\hline & & \multicolumn{2}{|c|}{0} & \multicolumn{2}{|c|}{$\mathbf{I}$} & \multicolumn{2}{|c|}{2} \\
\hline & & Dust-exposed & No Exposure & Dust-exposed & No Exposure & Dust-exposed & No Exposure \\
\hline $\begin{array}{l}\mathrm{Nil} \\
0-2 \\
2-4 \cdot 9 \\
5-9 \cdot 9 \\
10+\end{array}$ & $\begin{array}{l}\cdots \\
\cdots \\
\cdots \\
\cdots\end{array}$ & $\begin{array}{rr}309 & (93.7 \%) \\
2 & (0.6 \%) \\
7 & (2.1 \%) \\
8 & (2.4 \%) \\
4 & (1.2 \%)\end{array}$ & $\begin{aligned} 200 & (95.2 \%) \\
\text { I } & (0.5 \%) \\
8 & (3.8 \%) \\
\text { I } & (0.5 \%) \\
0 & (0 \%)\end{aligned}$ & $\begin{array}{r}22(18.2 \%) \\
5(4.1 \%) \\
27(22.3 \%) \\
42(34.7 \%) \\
25(20.7 \%)\end{array}$ & $\begin{array}{r}9(23.7 \%) \\
2(5.3 \%) \\
\text { II }(28.9 \%) \\
\text { IO }(26.3 \%) \\
6(15.8 \%)\end{array}$ & $\begin{array}{c}6(5.4 \%) \\
7(6.3 \%) \\
17(15.3 \%) \\
38(34.2 \%) \\
43(38.8 \%)\end{array}$ & $\begin{array}{l}3(17.6 \%) \\
0(0 \%) \\
1 \quad(5.9 \%) \\
6(35.3 \%) \\
7(41.2 \%)\end{array}$ \\
\hline Total & $\cdots$ & 330 & 210 & I2I & 38 & I I I & 17 \\
\hline
\end{tabular}

It will be seen from Table XIX that the dustexposed and non-dust-exposed groups present similar correlations for measured phlegm as against grade of phlegm, and there is no indication in this table that the dust-exposed group is exaggerating this symptom to any marked extent.

A further examination into the possibility of such bias in a separate paper does, however, present evidence that in the symptom of dyspnoea a bias to answering in a higher grade appears to be present in the mining group (Sluis-Cremer, Walters, and Sichel, 1967).

Socio-economic Status Socio-economic status may affect chronic bronchitis prevalence (Brown, McKeown, and Whitfield, 1958). It is, therefore, important that the two groups are very similar in this respect and represent a homogeneous community in socio-economic status and living conditions.

Atmospheric pollution can be ignored as a factor in this study.

Methodology The complete survey was carried out by one interviewer and the problem of interobserver variation does not therefore arise.

The application of this questionnaire to another language group has been successfully carried out before (Olsen and Gilson, 1960).

Chronic Bronchitis Prevalence For both definition I and definition II (Tables VIII and XIV respectively) there is clearly a much higher rate of chronic bronchitis in the dust-exposed.

The close relationship of chronic bronchitis to smoking is clearly shown in Tables XI, XII, and XIII for definition I and for the more severe form as defined by definition II in Tables XV and XVI.

It is also clear that although smoking greatly increases the prevalence of chronic bronchitis, the actual amount smoked has little demonstrable influence. This finding applies to both definitions and, in addition, suggests that the small difference in the amount smoked between the dust-exposed and nondust-exposed groups is of no importance.

A significant difference between dust-exposed and non-dust-exposed groups in prevalence of chronic bronchitis (definition I) exists for both present smokers and past smokers but not for persons who had never smoked. This also holds for the different grades of smokers where adequate samples exist (Table XII).

The higher rates for non-smokers among the dust-exposed group in Tables XI and XII are due to the inclusion of the ex-smokers among the nonsmokers.

Tables IX and XVI show that the prevalence of chronic bronchitis is far more dependent on age among the non-dust-exposed than among the dustexposed group for both definitions of chronic bronchitis. This suggests that in the dust-exposed group the factors causing chronic bronchitis, i.e., smoking, act more rapidly and completely on the susceptible section of the population. Similarly, Table $\mathrm{X}$ indicates that chronic bronchitis has nearly reached a maximum prevalence $(50.5 \%)$ in the II-I 5 years' service group and that in the longer service groups there is little tendency to increase. This trend is present in most of the age groups with the possible exception of those over 55 years.

That dust inhalation is not the sole and direct cause of the differences in chronic bronchitis rate is strongly indicated by the fact that miners who have never smoked do not show an excess rate for chronic bronchitis. The situation is similar to that in Yokohama asthma where the majority of those affected are smokers. Aerial pollution appears to require the action of a co-factor, i.e., smoking, to 
cause serious disease and disability (Phelps and Koike, 1962). That dust is not a major factor is also suggested by the fact that the silicotics do not have a further significant excess of chronic bronchitis (Tables XVII and XVIII). However, the sample is unfortunately rather small.

A comparison between the prevalence of chronic bronchitis in those working on surface installations exposed to dust only and those working underground and exposed to the total underground environment was not possible from our data. The majority of the miners, however, had underground service, and it seems reasonable to seek the factors causing the prevalence of chronic bronchitis underground. These factors may be physical, i.e., temperature variations, or chemical, i.e., fumes. Nitrous fumes have been shown to cause emphysema in experimental animals at low concentrations and there are indications that concentrations below 5 p.p.m. (the maximal allowable concentration underground) are not innocent, in this regard, in animals (Haydon, Freeman, and Furiosi, 1965). This concentration, however, appears insignificant in comparison with the \pm 200 p.p.m. or more of nitrous fumes that are found in cigarette smoke (Bokhoven and Niessen, 196I).

Little is known of the relevant prevalence of viral and other respiratory tract infections in miners and whether underground conditions are more conducive to the spread of these infections. Over-

TABLE XX

Prevalence of Chronic Bronchitis in Various Countries

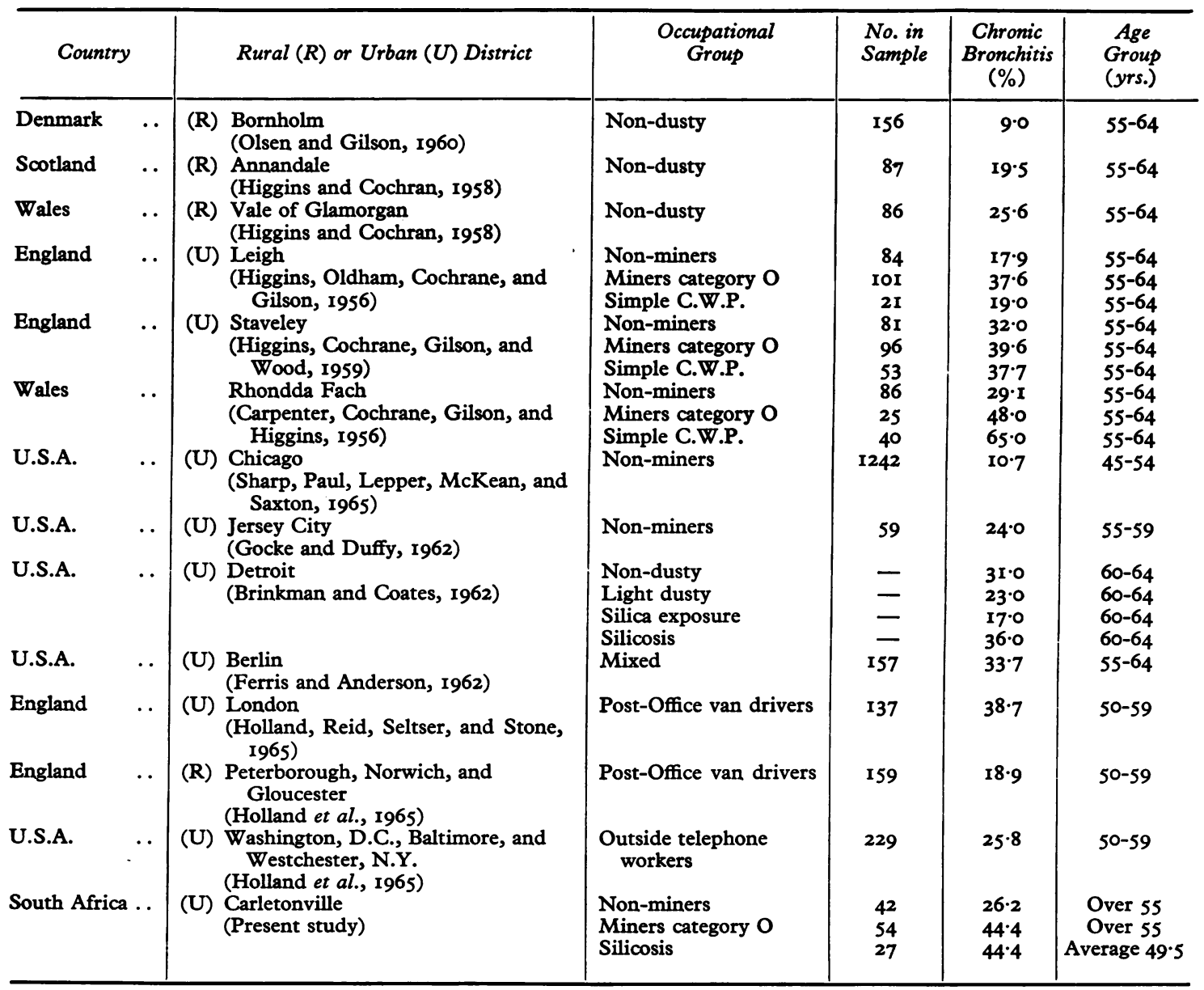

C.W.P. = coalworkers' pneumoconiosis. 
crowding, i.e., in cages, may also be a factor in this regard.

No factor or combination of factors can on present evidence be indicated as the cause of the high rate of chronic bronchitis in miners apart from the fact that smoking is a sine qua non. Further studies into this problem are clearly indicated.

International Comparisons of Chronic Bronchitis Prevalence Table XX shows the prevalence of chronic bronchitis reported in similar surveys in several countries. Definition I, or some closely related definition, was used in these surveys.

The prevalence of chronic bronchitis in nonminers at Carletonville is similar to that in urban populations in the United Kingdom and the United States. Gold-miners (without silicosis) have a similar incidence to coal-miners (without coalworkers' pneumoconiosis) at Leigh, Staveley, and the Rhondda Fach.

The fact that there is no significant air pollution in Carletonville strongly suggests that smoking is a far more significant factor in the causation of chronic bronchitis than air pollution or climate.

This survey has produced no data about the severity of chronic bronchitis in South Africa. It is generally believed that the condition more often takes a more serious course in the United Kingdom than elsewhere. The relative severity of the condition in South Africa and whether there are in this respect differences between miners and non-miners requires further study.

We gladly acknowledge the outstanding manner in which Mr. C. S. Rautenbach, the field officer for this survey, acquitted himself of his task.

We appreciate the advice and assistance given by Dr. J. C. Gilson at various times before and during the survey.
REFERENCES

Böhme, A., and Lent, H. (I95I). Beitr. Silikose-Forsch., heft II, p. I.

Bokhoven, C., and Niessen, H. J. (I96I). Nature (Lond.), 192, 458.

Brinkman, G. L., and Coates, E. O. (1962). Amer. Rev. resp. Dis., 86, 47.

Brown, R. G., McKeown, T., and Whitfield, A. G. W. (1958). Brit. med.F., $\mathbf{1}, 555$.

Carpenter, R. G., Cochrane, A. L., Gilson, J. C., and Higgins, I. T. T. (1956). Brit. F. industr. Med., 13, 166.

Ferris, B. G., and Anderson, D. O. (1962). Amer. Rev. resp. Dis., 86, 165.

Gocke, T. M., and Duffy, B. J. (1962). Arch. intern. Med., 110, 606.

Haydon, G. B., Freeman, G., and Furiosi, N. J. (1965). Arch. environm. Hlth, II, 776.

Higgins, I. T. T. (1957). Brit. med.F., 2, I 198.

-, and Cochran, J. B. (1958). Tubercle (Lond.), 39, 296.

- , and Cochrane, A. L. (1961). Brit. F. industr. Med., 18,

- $\frac{93 .}{16}$, Gilson, J. C., and Wood, C. H. (I959). Ibid., 16, 255.

-, Oldham, P. D., Cochrane, A. L., and Gilson, J. C. (1956). Brit. med. F., 2, 904.

Holland, W. W., Reid, D. D., Seltser, R., and Stone, R. W. (1965). Arch. environm. Hlth, 10, 338.

Hyatt, R. E., Kistin, A. D., and Mahan, T. K. (1964). Amer. Rev. resp. Dis., 89, 387.

Olsen, H. C., and Gilson, J. C. (1960). Brit. med. F., 1, 450.

Orie, N. G. M., Sluiter, H. J., Vries, K. de, and Witkop, J. (1960). Belg. T. Geneesk., 16, 509.

Pemberton, J. (1956). A.M.A. Arch. industr. Hlth, 13, 529.

Phelps, H. W., and Koike, S. (1962). Amer. Rev. resp. Dis., 86, 55.

Sharp, J. T., Paul, O., Lepper, M. H., McKean, H., and Saxton, G. A. C. (1965). Ibid., 91, 5 10.

Sluis-Cremer, G. K., Walters, L. G., and Sichel, H. S. (1967). Brit. F. industr. Med., 24, 13.

Vyskčcil, J. (1964). Scr. med. Fac. Med. Brun., 37, 289.

Worth, G., Ibel, E., Durben, H. H., and Gasthaus, L. (1958). Beitr. Silikose-Forsch., heft 56, p. I.

Zwi, S. (1960). In Proceedings of the Pneumoconiosis Conference, fohannesburg, I959, ed. by A. J. Orenstein, p. 522. Churchill, London.

and Becklake, M. R. (1958). Brit. F. industr. Med., 15, 258. 